\title{
PENGAJARAN KOSAKATA BAHASA ARAB SISWA MELALUI MEDIA PERMAINAN POHON PINTAR
}

\author{
Sri Wahyuningsih, M.Pd.I \\ clie.wahyu1@gmail.com \\ (Dosen Fakultas Tarbiyah IAI Muhammadiyah Bima)
}

\begin{abstract}
الملخحص
المفردات هي واحد من عناصر الهامية في اللغة العربية، بعيدا عن علم النحو و الصرف و

الأصوت، اللغة العربية لديها المفردات لوظيفة و الدور و التأثير في تعليم اللغة، خاصية

تعليم اللغة العربية للطلاب الإندونيسي التي تعليم اللغة اللأجنبيه واحدة من وسـائل

اللإعلام التعلم في تعليم اللغة العربية باستخدام وسائل اللإعلام التعلم لعبة شجرة ذكية

(Pohon Pintar)، وسائل اللإعلام التعلم شجرة ذكية استخدامها علي تعليم المفردات علي

نوعاه و شكله، المثال وضع الطلاب المفردات إسم (مؤنث و مذكر) و فعل (ماض و مضارع و

أمر) التي حصل عليها الطلاب من المعلمين، بجعل بطاقة مثل الأوراق و الفواكهة إلي كل

المواد محملة وسـائل الإعلام التعلم لعبة شجرة ذكية، و سوف تحفيز الطلاب لإضيافة

المفردات أن أكثر كثافة أشجارهم.

كلمات المفتاح: المفردات، وسائل اللإعلام التعلم، لعبة شجرة ذكية

Kosakata merupakan salah satu unsur terpenting dalam bahasa termasuk bahasa Arab, disamping kaidah tata bahasa/ilmu nahwu (sintaksis), ilmu shorof (morfologi), dan ilmu ashwat (fonetik). Bahasa Arab memiliki kosakata yang mempunyai fungsi, peran, serta pengaruh yang besar dalam pembelajaran bahasa di dalamnya, terlebih lagi mempelajari bahasa Arab bagi pelajar Indonesia berarti juga mempelajari bahasa asing/ bahasa keduanya.

Salah satu media pembelajaran bahasa Arab dalam pembelajaran kosakata siswa adalah dengan penggunaan media permainan pohon pintar. Media permainan pohon pintar dapat diaplikasikan pada materi-materi bahasa arab diantaranya materi kosakata berdasarkan cabang pembagian jenis dan bentuk dari kosakata, contohnya siswa memetakkan kosakata yang mereka peroleh dari guru maupun buku-buku referensi dengan bentuk pola daun, buah dan bunga, sehingga keseluruhan materi dapat termuat dalam media pohon pintar tersebut. Dan akan memotivasi siswa dengan semakin bayak kosakata yang mereka ketahui maka semakin lebat dan besar pula pohon pintar yang mereka miliki.
\end{abstract}




\section{A. PENDAHULUAN}

Seiring dengan perkembangan zaman, kita tidak hanya dituntut mâhir dalam berbahasa Indonesia saja, akan tetapi juga perlu dikenalkan dengan bahasa- bahasa asing lainnya, seperti bahasa Arab. Bahasa Arab merupakan bahasa pengantar internasional yang amat penting. Karena Negara Indonesia merupakan bagian dari negara-negara yang ada di dunia, oleh karenanya jika bangsa Indonesia ingin maju dan berkembang, maka harus dapat berinteraksi di bidang politik, ekonomi, sosial, budaya, pertahanan, keamanan, dan pendidikan dengan berbagai negara di dunia melalui perantara bahasa internasional yang salah satu diantaranya adalah bahasa Arab.

Bahasa Arab sebagai bahasa asing menempati posisi penting di Indonesia, khususnya bagi umat Islam, tidak lain karena kedudukan bahasa Arab sebagai bahasa agama umat Islam. Bahasa Arab adalah bahasa Al-Qur'an dan Al Hadis, yang mana keduanya adalah landasan dasar agama Islam, serta bahasa bagi kebudayaan Islam seperti filsafat, ilmu kalam, ilmu hadis, tafsir dan lain sebagainya. Bangsa yang maju adalah bangsa yang peduli akan nasib generasi penerusnya, sedangkan bahasa merupakan kunci utama bagi generasi bangsa untuk membuka jendela dunia. Maka sebaiknya generasi penerus bangsa, perlu dikenalkan dan diajarkan bahasa Arab. Adapun salah satu cara dalam mengenalkan bahasa Arab kepada khalayak adalah dengan belajar dan pembelajaran.

Pembelajaran dilihat dari ruang lingkupnya terdiri dari beberapa komponen. Komponen tersebut meliputi tujuan, bahan pelajaran, kegiatan belajar mengajar, metode, alat, sumber belajar atau evaluasi. Semua komponen tersebut harus saling berkaitan satu sama lain untuk mencapai keberhasilan pendidikan sesuai dengan tujuan yang diinginkan. Keberhasilan suatu proses pembelajaran tidak dapat terlepas dari peran media didalamnya, sebab alat atau media pendidikan merupakan suatu bagian integral dari proses pendidikan di Sekolah. ${ }^{1}$

Kosakata merupakan salah satu unsur terpenting dalam bahasa termasuk bahasa Arab, disamping kaidah tata bahasa/ilmu nahwu (sintaksis), ilmu sharaf (morfologi), dan ilmu ashwât (fonetik). Setiap bahasa termasuk bahasa Arab memiliki kosakata yang mempunyai fungsi, peran, serta pengaruh yang besar dalam pembelajaran bahasa di dalamnya, terlebih lagi mempelajari bahasa Arab bagi pelajar Indonesia berarti juga mempelajari bahasa asing/ bahasa keduanya, oleh karenanya mempelajari/memperluas kosakata merupakan prasyarat dan tuntutan yang mendasari seseorang dalam menguasai

\footnotetext{
${ }^{1}$ Oemar Hamalik, Media Pendidikan, (Bandung: PT.Citra Andily Bakti, 1989), 1.
} 
bahasa kedua tersebut. Dengan penguasaan kosakata bahasa dengan baik, siswa didik akan mempunyai bekal ilmu pengetahuan tambahan yang berguna ketika memasuki jenjang pendidikan yang lebih tinggi dan yang terpenting adalah siswa didik dibekali kemampuan memahami kata sederhana dan melafalkan kosakata bahasa Arab dengan benar.

Namun dalam praktiknya di lembaga pendidikan, dalam pembelajaran bahasa Arab khususnya masih dijumpai berbagai masalah yaitu penguasaan kosakata bahasa Arab (mufradât) siswa belum optimal. Tidak adanya Indikator- indikator terkait penguasaan kosakata siswa yang berkembang optimal yang meliputi penguasan kosakata aktifproduktif (berbicara- menulis) maupun pasif-reseptif (membaca-menyimak). Adapun beberapa faktor yang menyebabkan kurangnya penguasaan kosakata bahasa Arab (mufradât) siswa yakni: faktor pertama, bahasa Arab merupakan bahasa kedua yang hanya dipelajari siswa ketika berada di sekolah; faktor kedua, monotonnya guru dalam menggunakan metode pembelajaran (konvensional); faktor ketiga, penggunaan media yang kurang variatif, sehingga pembelajaran sering disampaikan secara lisan saja tanpa ada media pendukung yang dapat menarik minat siswa saat guru menjelaskan materi; dan faktor keempat, guru cenderung sebagai pusat pembelajaran (Teacher Centered) dan siswa hanya mendengarkan materi. Metode ceramah dan tanya jawab serta penggunaan buku paket sebagai lembar kerja (LK) masih sering digunakan ketika menyampaikan materi sehingga siswa cepat merasa jenuh.

Salah satu bentuk inovasi yang dapat guru lakukan adalah dalam bentuk penggunaan media pembelajaran yang menarik dan sesuai dengan tujuan pembelajaran yang ingin dicapai. Media pembelajaran merupakan segala sesuatu yang dapat menyalurkan pesan, dapat merangsang pikiran, perasaan, dan kemauan peserta didik sehingga dapat mendorong terciptanya proses belajar pada diri peserta didik. Secara umum manfaat media pembelajaran adalah memperlancar interaksi antara guru dengan siswa sehingga kegiatan pembelajaran lebih afektif dan efisien, proses pembelajaran menjadi lebih jelas dan menarik. Media pembelajaran dapat menampilkan informasi melalui suara, gambar, gerakan dan warna, baik secara alami maupun manipulasi, sehingga membantu guru untuk menciptakan suasana belajar menjadi lebih hidup, tidak monoton dan tidak membosankan.

Begitu pula dalam pengajaran bahasa Arab yang biasanya sarat dengan materi pembelajaran yang cukup rumit dan identik dengan metode hafalan kosakata. Pada kasus 
semacam ini seorang guru bahasa Arab yang profesional dituntut untuk menguasai penggunaan media yang efektif dan efisien dalam proses pembelajaran untuk mencapai tujuan yang ditentukan. Dalam proses pembelajaran hendaknya guru harus memahami dan menguasai tentang media pendidikan dan pengajaran sehingga tujuan pembelajaran dapat berhasil dan efektif. Seperti halnya dalam pemilihan media sebagai alat pembelajaran. $^{2}$

Salah satu media pembelajaran yang mampu membantu meningkatkan kemampuan pembelajara bahasa Arab dalam memahami kosakata siswa adalah dengan penggunaan media permainan pohon pintar. Media permainan pohon pintar dapat diaplikasikan pada materi-materi bahasa arab diantaranya materi kosakata berdasarkan cabang pembagian jenis dan bentuk dari kosakata, contohnya siswa memetakkan kosakata yang mereka peroleh dari guru maupun buku-buku referensi dengan bentuk daun, buah dan bunga, sehingga keseluruhan materi dapat termuat dalam media pohon pintar tersebut. Dan akan memotivasi siswa dengan semakin bayak kosakata yang mereka ketahui maka semakin lebat dan besar pula pohon pintar yang mereka miliki.

Berdasarkan pendahuluan yang diuraikan diatas penulis akan menjelaskan tentang pembelajaran kosakata bahasa Arab melalui media pohon pintar. Dan untuk mempermudah pembahasan ini maka penulis merumuskan masalah sebagai berikut;

1. Apa yang dimaksud dengan penguasaan kosakata bahasa Arab?

2. Apa yang dimaksud dengan media permainan pohon pintar?

3. Bagaimana penerapan media permainan pohon pintar dalam meningkatkan penguasaan kosakata bahasa Arab siswa?

\section{B. PENGUASAAN KOSAKATA BAHASA ARAB}

Penguasaan berarti kemampuan dan kesanggupan (untuk berbuat sesuatu) atau perbuatan menguasai. Sedangkan kosakata adalah satuan terkecil yang ikut menentukan kekuatan bahasa. Bahasa Arab menurut penelitian para ahli dikenal kaya akan kosakata, terutama pada konsepkonsep yang berkenaan dengan kebudayaan dan kehidupan mereka sehari-hari. $^{3}$

Menurut Muhammad Ali Khuli dalam bukunya assalîb tadâris al-lughah alarabiyyah menyatakan bahwa penguasaan atau pengetahuan kosakata (mufradât) mempunyai faedah yang sangat penting sekali, karena penguasaan kosakata bermanfaat

\footnotetext{
2 Busyairi Madjidi, Metodologi Pengajaran Bahasa Arab, (Yogyakarta: Sumbangsih Offset, 1994), 1.

${ }^{3}$ Acep Hermawan, Metodologi Pembelajaran Bahasa Arab, (Bandung: Rosdakarya, 2011), 64.
} 
bagi orang yang ingin menulis atau mengarang bahkan belajar tentang bahasa Arab. ${ }^{4}$ Penguasaan bahasa bertujuan agar manusia dapat berkomunikasi dengan baik, maka seorang pembelajar harus menguasai kosakata, karena akan banyak membantu siswa didik dalam belajar bahasa asing (bahasa Arab) terutama dalam menguasai keempat keterampilan berbahasa yaitu keterampilan menyimak (mahâratul istima'), membaca (mahâratul qira'ah), berbicara (mahâratul kalâm) dan menulis (mahâratul kitâbah).

Adapun penguasaan bahasa menurut Mansuer Pateda dapat dilakukan secara aktif dan pasif. Penguasaan bahasa secara aktif adalah kemampuan untuk mengungkapkan pikiran dan gagasan dengan menggunakan bahasa yang baik melalui lisan dan tulis. Seseorang berbahasa secara aktif yaitu seseorang mampu mengungkapkan gagasan dan pikiran kepada orang lain, serta mampu memahami dan mengerti bahasa orang lain baik secara lisan maupun tulisan ${ }^{5}$.

Manusia mengungkapkan berbagai macam peristiwa dalam kehidupan sehari-hari dengan menggunakan kata-kata yang tersusun dalam kalimat, untuk itu penguasaan kosakata adalah suatu hal yang utama untuk dipelajari sebagai syarat untuk siswa yang ingin mahir dalam berbahasa. Karena kualitas berbahasa seseorang jelas tergantung pada kualitas kosakata yang dimiliki. Semakin banyak kosakata yang dimiliki semakin besar pula kemungkinan untuk terampil berbahasa ${ }^{6}$.

Adapun yang dimaksud dengan kosakata menurut Kamus Besar Bahasa Indonesia (KBBI) berarti perbendaharaan kata, atau dalam bahasa Arab dikenal dengan istilah almufradât (Inggris: vocabulary) adalah himpunan kata atau khazanah kata yang diketahui oleh seseorang atau etnis lain, atau merupakan bagian dari suatu bahasa tertentu, dengan kata lain defenisi kosakata bahasa Arab adalah perbendaharaan kata yang diketahui dan dimiliki sekelompok orang/etnis dalam bahasa Arab ${ }^{7}$. Sedangkan Soemargono mendefinisikan pengertian kosakata sebagai sejumlah kata yang disukai pemakainya ${ }^{8}$.

Djiwandono menjelaskan lebih lanjut bahwa penguasaan kosakata dibagi menjadi dua, yaitu penguasaan kosakata aktif- produktif dan pasi- freseptif, dimana penguasaan kosakata aktif-produktif (ekspresif) digunakan untuk keperluan berbicara dan menulis,

\footnotetext{
${ }^{4}$ M. Ali Khulli, Assaliiba Tadaris Al-Lughoh Al-Arabiyah, (Jakarta: Al-Adeeb Library, 1986), 89.

${ }^{5}$ Mansuer Padeta, Linguistik Sebagai Pengantar, (Bandung: Angkasa, 1994), 63.

${ }^{6}$ Henry Guntur Tarigan, Pengajaran Kosakata, (Bandung: Angkasa, 1989), 2.

${ }^{7}$ Harimurti Kridalaksana, Kamus Linguistik, (Jakarta: PT.Gramedia Pustaka Utama, 1993), 127.

${ }^{8}$ Soemargono, Kamus Prancis Indonesia, (Jakarta: Gramedia, 1991), 103.
} 
sedangkan penguasaan kosakata reseptif digunakan untuk keperluan menyimak dam membaca. ${ }^{9}$

Ada beberapa pembagian kosakata dalam konteks kemahiran bahasa antara lain yaitu:

1. Kosa kata untuk memahami (undestanding vocabulary) baik bahasa lisan ataupun teks

2. Kosa aka untuk berbicara (speaking vocabulary), dalam berbicara perlu menggunakan kosakata yang tepat baik dalam pembicaraan yang bersifat informasi ataupun yang bersifat formal

3. Kosa kata untuk menulis (writing vocabulary), penulisanpun membutuhkan kosakata yang tepat agar pembacanya tidak salah dalam megartikan dan memahaminya

Adapun tujuan dari pembelajaran mufradât yaitu:

1. Menambah pembedaharaan kosakata baru, dengan mempelajari mufrodat paling tida kita mempunyai tabungan pembendaharaan kosakata baru yang bisa digunakan ketika kita membutuhkannya untuk menyusun kalimat yang sempurna

2. Melatih melafalkan dengan baik dan benar, dengan belajar kosakata kita akan tahu cara melafalkannya secara baik dan benar dari segi makhorijul huruf dan panjang pendeknya sekiranya dapat dimengerti oleh yang mendengar

3. Memahami kosakata baru baik secara denotasi maupun konotasi, jauh dari itu kita dapat memahami arti kata yang sebelumnya tidak pernah kita tahu, baik arti secara denotasi atau konotasinya, sehingga kita tidak tertipu dengan adanya satu kata banyak arti atau sebaliknya

4. Mampu merangkainya menjadi satu bahasa lisan atau tulisan pada taraf yang lebih matang adalah kita mampu mengaplikasikannya dalam sebuah bahasa lisan atau tulisan dengan pemilihan kata yang tepat dan tersusun sehingga tercipta bahasa yang mudah dipahami dan mudah dimengerti

Menurut Faisal Hendra, terdapat tujuh prinsip dalam pembelajaran mufrodat, adapun prinsip- prinsip pembelajaran mufrodat yang dimaksud sebagaimana berikut;

1. Frequency, yaitu frekuensi penggunaan kata- kata yang tinggi dan sering itulah yang harus mejadi pilihan

2. Range, yaitu mengutamakan kata-kata yang banyak digunakan dinegara Arab maupun dinegara- negara non Arab atau di suatu negara tertentu yang mana kata-kata itu lebih sering dinakan

\footnotetext{
${ }^{9}$ Soenardi Djiwandono, Tes Bahasa dalam Pengajaran, (Bandung: ITB, 1996), 43.
} 
3. Availability, yaitu mengutamakan kosakata yang mudah dipelajari dan digunakan dalam berbagai media atau wacana

4. Familiarty, yaitu mendahulukan kata- kata yang sudah dikenal dan cukup familiar ذ كاء didengar, seperti penggunaan kata شمس lebih sering digunakan dari pada kata padahal keduanya sama maknanya

5. Coverage, kemampuan daya caup suatu kata untuk memiliki beberapa arti sehingga menjadi luas cakupannya, kata baitun lebih luas daya cakupnya dari kata manzil

6. Significance, yaitu mengutamakan kata- kata yang memiliki arti yang signifikan untuk menghindari kosakata umum yang banyak ditinggalkan atau kurang lagi digunakan

7. Arabism, mengutamakan kosakata Arab dari kosakata serapan yang diarabisasi dari bahasa lain, misalnya kata الهاتف harus diutamakan pemilihan katanya dari pada kata 10

Berdasarkan uraian di atas dapat disimpulkan bahwa penguasaaan kosakata bahasa Arab (mufradât) adalah kemampuan seseorang dalam menggunakan kosakata yang dimiliki untuk berkomunikasi dan mengungkapkan ide/ gagasan dengan lingkungannya baik secara lisan maupun tulisan yang ditandai dengan berkembangnya kemampuan dasar berbahasa yaitu menyimak, menulis, berbicara dan membaca menggunakan bahasa Arab.

Menurut Keraf terdapat 3 tahap penguasaan kosakata yang terjadi pada seseorang yaitu sebagai berikut. ${ }^{11}$

1. Masa kanak- kanak, pada masa ini anak hanya memerlukan istilah untuk menyebutkan kata- kata secara terlepas. Semakin dewasa, anak ingin mengetahui semua yang dilihat dan dirasakannya atau didengarnya setiap hari. Maka dari itu, peran orang tua dan orang- orang yang di sekitarnya sangat penting dalam perluasan kata- kata dasarnya.

2. Masa remaja, pada masa ini telah terjadi proses belajar, karena anak mulai belajar untuk menguasai bahasa dan memperluas kosakatanya secara sadar.

3. Masa dewasa, pada masa ini penguasaan kosakata semakin mantap karena seseorang semakin banyak terlibat dalam komunikasi dengan banyak orang.

\footnotetext{
${ }^{10}$ Faisal Hendra, Metodologi Pembelajaran Bahasa Arab, (Jakarta: DEPAG RI, 2006), 156.

${ }^{11}$ Gorys Keraf, Diksi dan Gaya Bahasa, (Jakarta: PT. Ikrar Mandiriabadi, 2008), 65-66.
} 
Dalam mengajarkan kosa kata pada siswa, ada beberapa langkah yang harus diperhatikan agar pembelajaran tersebut berhasil. Dalam hal ini Ismail Shinny dan Abdullah mengatakan bahwa sebaiknya mengajarkan kosakata melalui cara tahapan berikut ini: 1) Dengan cara menunjuk langsung pada benda (kosakata) yang diajarkan. 2) Dengan cara menghadirkan miniatur dari benda (kosakata) yang diajarkan. 3) Dengan cara memberikan gambar dari kosakata yang ingin diajarkan. 4) Dengan cara memperagakan dari kosa kata yang ingin disampaikan. 5) Dengan cara memasukkan kosa kata yang diajarkan dalam kalimat. 6) Dengan cara memberikan definisi dari kosa kata yang diberikan. ${ }^{12}$

Dalam pembelajaran kosakata (al-mufradāt) ada baiknya dimulai dengan kosakata dasar yang tidak mudah berubah, seperti halnya istilah kekerabatan, nama-nama bagian tubuh, kata ganti, kata kerja pokok serta beberapa kosa kata lain yang mudah untuk dipelajari. Metode yang bisa digunakan dalam pembelajarannya antara lain yaitu metode langsung, metode meniru dan menghafal, metode membaca, metode gramatikatranslation, metode pembelajaran dengan menggunakan media bergambar dan alat-alat peraga serta pembelajaran dengan lagu atau menyanyi Arab.

Berdasarkan definisi tersebut dapat disimpulkan bahwa penguasaan kosa kata merupakan jumlah kata yang dimiliki oleh seseorang atau kelompok orang atau merupakan kata-kata yang terdapat dalam suatu bahasa yang mengandung informasi makna dan pemakaiannya. Setiap bahasa memiliki keunikan dan ciri khas tersendiri. Dalam pembelajaran bahasa asing (Arab) yang berorientasi pada fungsi yang komunikatif, maka modal yang dibutuhkan oleh siswa agar dapat berbicara bahasa Arab dengan aktif yakni dengan menguasai kosa kata bahasa Arab sebanyak-banyaknya. Oleh karena itu, dalam pembelajaran siswa tidak dituntut untuk memahami dan menguasai seluruh kosakata bahasa Arab namun dibatasi pada materi pelajaran yang disesuaikan dengan kurikulum yang ditentukan sehingga tidak ada target maksimal berapa jumlah kata yang harus dikuasai siswa, sehingga kegiatan pembelajaran berjalan optimal.

\section{MEDIA PERMAINAN POHON PINTAR}

Sudah menjadi rahasia umum bahwa pelajaran bahasa Arab kurang diminati siswa. Tak heran jika siswa kurang aktif dan kurang motivasi dalam pembelajaran. Salah satu cara untuk mengatasi sikap pasif dan menumbuhkan minat belajar siswa adalah

\footnotetext{
${ }^{12}$ Abd Wahab Rosyidi \& Mamlu'atul Ni'mah, Memahami Konsep Dasar Pembelajaran Bahasa Arab, (Malang: UIN-Maliki Press, 2011), 123.
} 
dengan menggunakan media pembelajaran ${ }^{13}$. Media pembelajaran merupakan semua sumber yang diperlukan untuk melakukan komunikasi dengan pebelajar. Salah satu media yang menarik dan menyenangkan adalah dengan media permainan. Peneliti memilih mengembangkan media pembelajaran dengan permainan karena berdasarkan pendapat para ahli dan diperkuat dengan beberapa penelitian menyatakan bahwa permainan efektif dapat digunakan dalam pembelajaran.

Istilah permainan menurut pengertiannya adalah situasi atau kondisi tertentu saat seseorang mencari kesenangan atau kepuasan melalui suatu aktifitas atau kegiatan bermain, bermain adalah suatu kegitan yang dilakukan dengan atau tanpa menggunakan alat yang menghasilkan pengertin atau memberi informasi, memberi kesenangan, maupun mengembalikan imajinasi pada anak ${ }^{14}$.

Menurut Yulianti, bermain merupakan suatu proses alamiah yang dengan sendirinya dilakukan oleh anak-anak. Melalui suatu permainan, diharapkan siswa dapat memperoleh kesenangan tanpa adanya paksaan ${ }^{15}$. Selanjutnya Sadiman, mengatakan bahwa permainan adalah setiap kontes antara pemain yang berinteraksi satu sama lain dengan mengikuti aturan-aturan tertentu untuk mencapai tujuan-tujuan tertentu. Dengan demikian, melalui permainan dapat disisipkan materi pelajaran sehingga siswa tidak hanya bermain tetapi mereka juga dapat melakukan proses belajar ${ }^{16}$.

Permainan sebagai suatu media pembelajaran memiliki beberapa kelebihan, diantaranya permainan adalah sesuatu yang menyenangkan untuk dilakukan, sesuatu yang menghibur. Permainan memungkinkan adanya partisipasi aktif dari siswa untuk belajar. Permainan memberikan pengalaman-pengalaman nyata dan dapat membantu siswa untuk meningkatkan kemampuan kognitifnya ${ }^{17}$. Beberapa manfaat belajar sambil bermain adalah menyingkirkan keseriusan yang menghambat, menghilangkan stres dalam lingkungan belajar, mengajak siswa terlibat penuh dalam pembelajaran, meningkatkan proses belajar, membangun kreativitas diri, mencapai tujuan dengan

13 Arief Sadiman, dkk. Media Pendidikan, Pengertian Pengembangan dan Pemanfaatannya. (Jakarta: Pustekkom Dikbud dan PT Raja Grafindo Persada. 2002), 16.

${ }^{14}$ Fathul Mujib dan Nailur rahmawati, Metode Permainan- Permainan Edukatif Dalam Belajar Bahasa Arab (Yogyakarta: Diva Press, 2011), 26.

${ }^{15}$ Rani Yulianty, Permainan yang Meningkatkan kecerdasan Anak Modern dan Tradisional. (Jakarta: Laskar Aksara, 2011), 7.

${ }^{16}$ Arief Sadiman, dkk. Media Pendidikan 75 .

17 Ibid., 78. 
ketidaksadaran, meraih makna belajar melalui pengalaman, dan memfokuskan siswa sebagai subjek belajar. ${ }^{18}$.

Riyana menjelaskan bahwa melalui media suatu proses pembelajaran bisa lebih menarik dan menyenangkan (joyfull learning), misalnya siswa yang memiliki ketertarikan terhadap warna maka dapat diberikan media dengan warna yang menarik. Begitu juga halnya dengan siswa yang senang berkreasi selalu ingin menciptakan bentuk atau objek yang diinginkannya, siswa tersebut dapat diberikan media yang sesuai, seperti plastisin, media balok bangun ruang, atau diberikan media gambar lengkap dengan catnya $^{19}$.

Kontribusi media belajar lewat bermain di sekolah- sekolah adalah salah satu upaya mengembalikan kesan kalau belajar tidak menjemukan, menakutkan, sulit dan membosankan, tetapi menjadi suatu aktivitas yang menyenangkan, efektif, mudah, dan bermanfaat bagi siapa pun juga ${ }^{20}$.

Adapun permainaan bahasa memiliki ciri- ciri sebagai berikut. ${ }^{21}$

1. Dapat mengukuhkan dan meningkatkan penguasaan bahasa, seperti mendengar, berbicara, membaca dan menulis, selain itu juga dapat meningkatkan penguasaan unsur bahasa (kosakata dan tata bahasa)

2. Mempuyai ransangan dan bahan yang menarik sesuai dengan tingkat penguasaa bahasa siswa

3. Memebri peluang kepada siswa untuk berinteraksi dengan siswa yang lain, guru dan materi bahasa

4. Dapat merangsang siswa untuk bertindak secara aktif dan positif serta dapat meningkatkan minat mereka

5. Melibatkan pelajar secara aktif baik dalam kelompok maupun kelas

Kemudian manfaat- manfaat dari permainan bahasa yaitu ${ }^{22}$;

1. Menyingkirkan keseriusan yang menghambat proses belajar

2. Menghilangkan stres dalam lingkungan belajar

3. Mengajar orang terlibat secara penuh

4. Meningkatkan proses belajar

\footnotetext{
${ }^{18}$ Yusuf, Yasin dan Umi Auliya, Sirkuit Pintar Melejitkan Kemampuan Matematika \& Bahasa Inggris dengan Metode Ular Tangga, (Jakarta: Visimedia, 2011), 17.

${ }^{19}$ Rayandra Asyhar, Kreatif Mengembangkan Media Pembelajaran, (Jakarta: Referensi, 2012), 29.

${ }^{20}$ Fathul Mujib dan Nailur Rahmawati, Metode Permainan

${ }^{21}$ Ibid., 54.

${ }^{22}$ Ibid., 36.
} 
5. Membangun kreatifitas diri

6. Mencapai tujuan dengan ketidak sadaran

7. Meraih makna belajar melalui pengalaman dan

8. Memfokuskan siswa sebagai subyek belajar

Dalam memilih permainan bahasa dalam proses pembelajaran bahasa Arab, maka harus memperhatikan hallhal berikut: Pertama; Pengajar harus menentukan batasan yang jelas, sehingga memungkinkan untuk memilih permainan bahasa yang sesuai. Kedua; Permainan bahasa harus sesuai dengan tingkatan pengajaran, kemampuan peserta didik, waktu, dan tempat yang tersedia. Ketiga; Rasa aman yang melingkupi siswa jangan sampai menimbulkan penyimpangan. Keempat; Harus memperhatikan keterampilan berbahasa, unsurunsur bahasa dan model bahasa agar pelaksanaan latihan bahasa dengan "permainan" menjadi sempurna. Kelima; Jika permainan membutuhkan persiapan yang khusus, maka lebih baik persiapan dilakukan sebelum permainan dilaksanakan. Keenam; Sebelum permainan dimulai harus diyakinkan bahwa siswa telah memahami tatacara pelaksanaan permainnan. ${ }^{23}$

Media pohon pintar kosakata merupakan media yang cocok untuk siswa yang ingin bermain dengan warna dan berkreasi sesuai materi pelajaran. Siswa dengan segala kreatifitasnya, dengan dipandu oleh guru, merancang dan membuat media pohon pintar kosakata sebagai langkah untuk membangun keaktifan siswa sekaligus mengolah informasi yang ada sebelum nantinya bisa juga dipresentasikan di depan kelas untuk tingkat kelas yang lebih tinggi setara Madrasah Tsanawiyah (MTs), Madrasah Aliyah (MA) atau Perguruan Tinggi.

Pohon pintar menjadi salah satu media pembelajaran yang dapat dikembangkan. Pohon pintar juga menjadi media pembelajaran yang interaktif antara guru dengan siswa dan siswa dengan siswa. Dengan adanya media pembelajaran pohon pintar akan terdapat pembelajaran yang interaktif akan melibatkat interaksi antara guru dan siswa. Pohon pintar didesain sesuai dengan pohon yang nyata.

Dengan adanya gambar, warna dan berbagai bentuk akan meningkatkan kemapuan memahami mengenai materi tersebut. Kegiatan ini akan merangsang siswa untuk berfikir dan menggerakkan anggota tubuh sehingga segala aspek dari tubuh akan bergerak. Hal ini akan mampu meningkatkan kemampuan memahami materi karena

${ }^{23}$ Umi Hijriyah, Media Pembelajaran Bahasa Arab Dan Media Permainan Bahasa Arab, (Lampung; Fakta Press Fakultas Tarbiyah IAIN Raden Intan Lampung, 2015), 57. 
siswa dituntut untuk bergerak dan berfikir untuk menciptakan suatu pohon yang terdapat materi tersebut

Pengertian pohon adalah: tumbuhan yang berbatang keras dan besar. Dan bahagian yang permukaan atau yang dianggap pangkal, dasar. Sedangkan pengertian pintar yaitu: pandai, cakap, cerdik, banyak akal dan mahir mengerjakan sesuatu. ${ }^{24}$ Dari keterangan di atas dapat disimpulkan permainan mengenal angka melalui pohon pintar yaitu suatu alat permainan menggunakan sebatang pohon yang telah dibentuk semenarik mungkin serta menggunakan angka sehingga dapat membantu anak dalam meningkatkan potensi dan kecerdasan, kreativitas yang ada dalam diri anak agar berkembang secara optimal sesuai dengan pertumbuhan dan aspek perkembangan anak.

\section{MEDIA PERMAINAN POHON PINTAR DALAM PEMBELAJARAN KOSAKATA BAHASA ARAB SISWA}

Media Pohon Pintar termasuk media visual tiga dimensi. Daryanto mengatakan media tiga dimensi ialah sekelompok media tanpa proyeksi yang penyajiannya secara visual tiga dimensional. Kelopok media ini dapat berwujud sebagai benda asli baik hidup maupun mati, dan dapat pula berwujud sebagai tiruan yang mewakili aslinya. Media tiga dimensi yang dapat diproduksi dengan mudah, adalah tergolong sederhana dalam penggunaan dan pemanfaatannya, karena tanpa harus memerlukan keahlian khusus, dapat dibuat sendiri oleh guru, bahannya mudah diperoleh di lingkungan sekitar. ${ }^{25}$

Pengajaran kosakata bahasa Arab melalui permainan pohon pintar membutuhkan bermacam - macam bahan dan alat seperti dibawah ini :

1. Bahan: Kertas manila putih, hijau, merah , spidol/ krayon, seloti/ lem, gunting, kosakata bahasa Arab

2. Adapun cara dan langkah- langkah yang dilakukan dalam membuat pohon pintar yaitu:

a) Menyiapkan bahan.

b) Menggambar batang pohon beserta cabang dan ranting- rantingnya pada kertas manila putih dengan menggunakan spidol atau krayon.

c) Tempel kertas manila yang sudah bergambar pohon di dinding kelas.

\footnotetext{
${ }^{24}$ Dekdibud, Kamus Bahasa Indonesia, (1988), 686, 691.

25 Daryanto. Media Pembelajaran: Peranannya Sangat Penting Dalam Mencapai Tujuan Pembelajaran. (Yokyakarta: Penerbit Gava Media, 2013), 29.
} 
d) Gunting kertas manila warna hijau membentuk daun sedangkan manila warna merah digunting membentuk buah, kemudian rekatkan selotip aau lem di bagian belakang kertas daun dan buah.

e) Kosakata ditulis siswa sendiri ketika akan mulai permainan

Penyajian atau pelaksanaan dari permainan melalui pohon pintar dilaksanakan secara kelompok dengan metode praktek langsung dan pemberian tugas. Adapun cara penyajian dari permainan ini adalah sebagai berikut :

1. Guru menyediakan alat peraga atau media yang digunakan.

2. Guru memperkenalkan permainan dengan pohon pintar kepada anak dengan menggunakan metode tanya jawab.

3. Guru menjelaskan cara memainkan alat permainan tersebut kepada anak dengan cara memperagakannya serta menetapkan aturan bermain, adapun cara memainkannya adalah : siswa akan dipersilahkan melihat dan mendengar kosa kata terlebih dahulu dari guru, kemudian setelah jangka waku yang ditetapkan siswa akan dipersilahkan megambil kertas pola daun dan buah berdasaran pembagiannya (misalnya daun untuk kata $i \operatorname{sim}$ dan buah untuk kata $f i$ 'il)

4. Guru menetapkan aturan bermain kepada anak agar anak dapat bermain dengan tertib sesuai aturan yang telah disepakati bersama.

5. Guru mempersilahkan siswa untuk mendengarkan dan menulis mufradât pada kertas pola setelah diberikan soal oleh guru, secara bergiliran (contoh; guru menyuruh siswa menuliskan kata "buku" ke dalam bahasa Arab)

6. Guru memberikan motivasi atau bimbingan serta penghargaan kepada anak dalam melaksanakan permainan.

Contoh gambar permainan pohon pintar:

\section{E. KESIMPULAN}

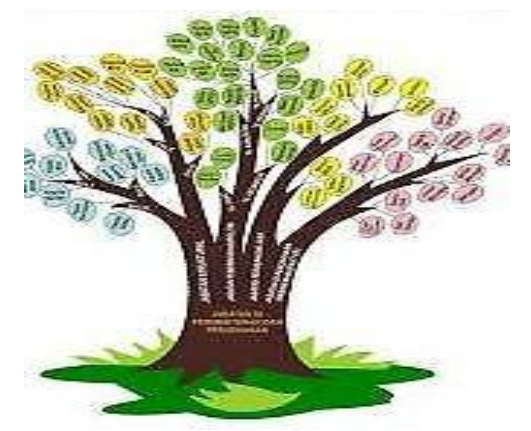

Kosa kata sebagai fondasi dasar berbahasa Arab sangat penting dimiliki siswa untuk mengungkapkan ide dan gagasannya baik secara lisan maupun secara tertulis. Untuk mendukung tercapainya kemampuan tersebut, dibutuhkan media sebagai penyambung untuk mendorong serta dapat meningkatkan kemampuan siswa baik secara kualitatif 
maupun kuantitif dalam menguasai jumlah mufradât. Media permainan pohon pintar sebagai ikhtiar untuk mendorong serta memacu daya kreatifitas dan semangat guru dan siswa dalam pembelajaran bahasa Arab sehingga terjadi interaksi yang produktif antara keduanya terutama dalam proses belajara mengajar.

Dengan pembelajaran yang interkasif melalui media permainan pohon pintar, siswa memiliki keberanian dalam berbahasa Arab. Dengan demikian, tujuan pembelajaran bahasa Arab yang dapat mendorong peserta didik agar bersikap positif terhadap bahasa Arab akan tercapai. Ketercapain tujuan ini membutuhkan kerja keras dan kerja tuntas dari seorang guru dalam kegiatan belajar agar media berfungsi dengan baik dan berfungsi serta tepat guna sesuai kebutuhan kegiatan belajar. 


\section{DAFTAR PUSTAKA}

Abd Wahab Rosyidi \& Mamlu'atul Ni'mah, Memahami Konsep Dasar Pembelajaran Bahasa Arab, Malang: UIN-Maliki Press, 2011.

Acep Hermawan, Metodologi Pembelajaran Bahasa Arab. Bandung: Rosdakarya, 2011

Arief Sadiman, dkk. Media Pendidikan, Pengertian Pengembangan dan Pemanfaatannya.

Jakarta: Pustekkom Dikbud dan PT Raja Grafindo Persada. 2002

Busyairi Madjidi, Metodologi Pengajaran Bahasa Arab, Yogyakarta: Sumbangsih Offset, 1994.

Daryanto. Media Pembelajaran: Peranannya Sangat Penting Dalam Mencapai Tujuan Pembelajaran. Yokyakarta: Penerbit Gava Media, 2013.

Dekdibud, Kamus Bahasa Indonesia, 1988.

Faisal Hendra, Metodologi Pembelajaran Bahasa Arab, Jakarta: DEPAG RI, 2006

Fathul Mujib dan Nailur rahmawati, Metode Permainan- Permainan Edukatif Dalam Belajar Bahasa Arab, Yogyakarta: Diva Press, 2011.

Gorys Keraf, Diksi dan Gaya Bahasa. Jakarta: PT. Ikrar Mandiriabadi, 2008

Harimurti Kridalaksana, Kamus Linguistik. Jakarta: PT.Gramedia Pustaka Utama, 1993

Henry Guntur Tarigan, Pengajaran Kosakata. Bandung: Angkasa, 1989.

M. Ali Khulli, Assaliiba Tadaris Al-Lughoh Al-Arabiyah. Jakarta: Al-Adeeb Library, 1986

Mansuer Padeta, Linguistik Sebagai Pengantar. Bandung: Angkasa, 1994

Oemar Hamalik, Media Pendidikan, Bandung: PT.Citra Andily Bakti, 1989.

Rani Yulianty, Permainan yang Meningkatkan kecerdasan Anak Modern dan Tradisional.

Jakarta: Laskar Aksara, 2011.

Rayandra Asyhar, Kreatif Mengembangkan Media Pembelajaran. Jakarta: Referensi, 2012

Soemargono, Kamus Prancis Indonesia (Jakarta: Gramedia, 1991), 103.

Soenardi, Djiwandono,Tes Bahasa dalam Pengajaran. Bandung: ITB, 1996

Umi Hijriyah, Media Pembelajaran Bahasa Arab Dan Media Permainan Bahasa Arab, Lampung; Fakta Press IAIN Raden Intan Lampung, 2015.

Yusuf, Yasin dan Umi Auliya, Sirkuit Pintar Melejitkan Kemampuan Matematika \& Bahasa Inggris dengan Metode Ular Tangga. Jakarta: Visimedia, 2011. 